\title{
Kekuatan Klausula Pengaman Diri Dalam Akta Bagi Notaris
}

\author{
Andi Listiana \\ Fakultas Hukum Universitas Islam Indonesia Yogyakarta Indonesia \\ Jln. Cik Di Tiro No. 1 Yogyakarta Indonesia \\ andilistianasulaeman@gmail.com
}

\begin{abstract}
The purpose of this research is to identify the legal binding force of the Notary's self-security clause in the deed if there is a client who denies it and to analyse whether the self-security clause in the Partij deed can provide legal protection for Notaries in carrying out their duties and functions. This research was conducted using the empirical juridical method, namely how the law is implemented in social life. Primary data were obtained from interviews, and while the secondary ones were from literature studies and the laws. The result of the research concludes that the responsibility of the notary is limited to the formal truth in a deed. Notaries have no responsibility to judge the material truth of the information obtained from the clients. Subsequently, in the event of the party in the deed accuses or argues that the Notary has included false information in the authentic deed shall not justifiable as the Notary is not a party to the deed.
\end{abstract}

Key Words: Authentic deed; notary; self-security clause

\begin{abstract}
Abstrak
Tujuan dalam penelitian ini adalah untuk mengetahui kekuatan hukum klausul pengamanan diri Notaris dalam akta jika ada penghadap yang menyangkal dan untuk mengetahui klausul pengamanan diri dalam akta Partij dapat memberikan perlindungan hukum bagi Notaris dalam menjalankan tugas dan jabatannya. Penelitian ini dilakukan dengan metode yuridis empiris yakni bagaimana hukum terlaksana di dalam kehidupan bermasyarakat. Data primer bersumber dari wawancara, dan data sekunder bersumber dari literatur, buku-buku, maupun undang-undang. Hasil penelitian menyimpulkan bahwa tanggung jawab Notaris hanya sebatas kebenaran formil di dalam suatu akta. Notaris tidak mempunyai tanggung jawab untuk menilai kebenaran materiil dari informasi yang diperoleh dari para penghadap. Dapat disimpulkan bahwa, bilamana pihak yang ada dalam akta menuduh atau mendalilkan bahwa Notaris telah mencantumkan keterangan palsu dalam akta autentik maka hal tersebut tidaklah dibenarkan karena Notaris bukanlah pihak di dalam suatu akta.
\end{abstract}

Kata-kata Kunci: Akta autentik; klausul pengaman diri; notaris 


\section{Pendahuluan}

Negara Kesatuan Republik Indonesia merupakan negara hukum yang berlandaskan atas Pancasila dan UUD 1945. Oleh karena itu, untuk menjamin kepastian, ketertiban, dan perlindungan hukum bagi setiap warga negara dibutuhkan alat bukti tertulis yang bersifat autentik mengenai semua perbuatan, perjanjian, penetapan, dan peristiwa hukum yang dibuat di hadapan atau oleh Notaris. Jabatan Notaris merupakan pejabat umum yang tentunya sudah tidak asing lagi bagi masyarakat. Notaris lahir atau ada karena masyarakat membutuhkannya, bukan karena sengaja diciptakan kemudian disosialisasikan kepada khalayak. Selain itu Notaris juga mempunyai posisi yang netral karena tidak ditempatkan di lembaga yudikatif ataupun eksekutif.

Berbicara tentang Notaris banyak masyarakat awam yang menyebut bahwa Notaris adalah tukang buat akta. Hal itu karena kurangnya pengetahuan dan sosialisasi kepada masyarakat. Padahal setiap masyarakat membutuhkan seseorang (figuur) yang keterangannya dapat diandalkan, dapat dipercayai, yang tanda tangannya serta segelnya (capnya) memberi jaminan dan bukti kuat, seorang ahli yang tidak memihak dan penasihat yang tidak ada cacatnya (onkreukbaar atau unimpeachable), yang tutup mulut dan membuat suatu perjanjian yang dapat melindunginya dihari-hari yang akan datang. Kalau seseorang advokat membela hak-hak sesorang ketika timbul suatu kesulitan, maka seorang notaris harus berusaha mencegah terjadinya suatu kesulitan itu. ${ }^{1}$ Kehadiran Notaris sangat erat kaitannya dalam kehidupan masyarakat. Karena untuk membuat sebuah alat bukti autentik masyarakat membutuhkan jasa seorang Notaris yang dapat memberikan jaminan kepastian hukum baik dalam hal ekonomi, sosial, dan politik. ${ }^{2}$

Akta autentik menurut kamus hukum adalah akta yang sejak awal dibuat dengan sengaja dan resmi untuk pembuktian apabila terjadi sengekta dikemudian hari. ${ }^{3}$ Akta autentik menurut Pasal 1868 Kitab Undang-Undang Hukum Perdata (KUH Perdata) adalah suatu akta yang dibuat dalam bentuk yang ditentukan undang-undang oleh atau dihadapan pejabat umum yang berwenang untuk itu ditempat akta itu dibuat. Jadi berdasarkan defenisi tersebut maka dapat diketahui bahwa ada 2 bentuk akta autentik yaitu akta yang dibuat oleh pejabat umum yang berwenang (disebut sebagai akta pejabat/ambtelijke acte) dan akta yang

1 Tang Thong Kie, Studi Notariat dan Serba-Serbi Praktek Notaris, Cetakan Kedua, PT Ichtiar Baru Van Hoeve, Jakarta, 2011, hlm. 449.

2 R.Subekti, Hukum pembuktian, Cetakan Kedua, Pradnya Paramita, Jakarta, 2001, hlm. 48.

3 M. Marwan \& Jimmy P, Kamus Hukum, Dictionary of Law Complate Edition, Cetakan kesatu, Reality Pulisher, Jakarta, 2009, hlm. 31. 
dibuat dihadapan pejabat umum yang berwenang (disebut sebagai partij acte/akta para pihak).

Menurut Sjaifurrachman, perbedaan dua macam sifat akta itu adalah sebagai berikut:

1. Dalam akta pejabat (ambtelijke atau verbal acte), akta ini masih sah sebagai suatu alat pembuktian apabila ada satu atau lebih diantara penghadapnya tidak menandatangani akta, sepanjang Notaris menyebutkan alasan pihak yang tidak menandatangani akta tersebut. ${ }^{4}$

2. Tidak ditandatanganinya akta di dalam partij acte akan menimbulkan akibat yang lain. Apabila salah satu pihak tidak membubuhkan tanda tangannya dalam partij acte maka dapat diartikan pihak tersebut tidak menyetujui isi akta yang dibuatnya, kecuali apabila tidak menandatangani akta itu didasarkan atas alasan yang kuat. Alasan yang dapat diterima untuk tidak membubuhkan tanda tangan didalam partij acte harus dicantumkan dengan jelas oleh Notaris dalam akta yang bersangkutan. ${ }^{5}$

Akta autentik pada dasarnya memuat kebenaran formal tergantung dengan apa yang diberitahukan masyarakat atau para pihak yang bersangkutan kepada Notaris. Namun, Notaris mempunyai kewajiban untuk memastikan bahwa apa yang termuat dalam akta Notaris sungguh-sungguh telah dimengerti dan sesuai dengan kehendak para pihak, yaitu dengan cara membacakannya sehingga menjadi jelas isi akta Notaris, serta memberikan akses terhadap informasi mengenai peraturan perundang-undangan yang terkait bagi para pihak penandatangan akta. Dengan demikian, para pihak dapat menentukan dengan bebas untuk menyetujui atau tidak isi akta Notaris yang akan ditandatanginya. Tanda tangan pada suatu akta autentik tersebut berfungsi sebagai tanda persetujuan terhadap kewajiban-kewajiban yang melekat pada akta.

Notaris yang merupakan pejabat umum yang mempunyai profesi dalam memberikan jasa kepada masyarakat sangat penting untuk mendapatkan perlindungan dan jaminan agar tercapainya kepastian hukum. Hal tersebut telah diatur dalam Undang-Undang Nomor 2 Tahun 2014 tentang perubahan atas Undang-Undang Nomor 30 Tahun 2004 tentang Jabatan Notaris. ${ }^{6}$ Sesuai dengan kewenangannya, seorang Notaris berwenang untuk membuat akta autentik yang

4 Sjaifurrachman, Aspek Pertanggungjawaban Notaris dalam Pembuatan Akta, Cetakan Pertama, Mandar Maju, Bandung, 2011, hlm. 109.

${ }^{5}$ Ibid., hlm. 110.

6 Abdul Ghofur Anshori, Perspektif Hukum Dan Etika, Lembaga Kenotariatan Indonesia, Cetakan Pertama, UII Press, Yoyakarta, 2009, hlm. 6. 
diatur dalam Pasal 15 ayat (1), (2) dan ayat (3) Undang-Undang Nomor 2 Tahun

2014. ${ }^{7}$ Kekuatan pembuktian akta autentik dapat dilihat dari:

1. Kekuatan pembuktian lahiriah

Kekuatan pembuktian lahiriah merupakan kemampuan akta autentik dapat membuktikan dirinya sendiri. Apabila ada salah satu pihak yang menyangkal akan akta autentik, maka pihak yang menyangkal tersebut harus membuktikannya. akta autentik dikatakan sempurna sejak akta tersebut telah memenuhi ketentuan Pasal 1868 KUHPerdata dan akta selama akta tersebut diakui keberadaannya oleh para pihak ${ }^{8}$

2. Kekuatan pembuktian formil

Kekuatan pembuktian formil berkaitan dengan kebenaran tentang suatu peristiwa yang terjadi. Notaris sebagai pejabat umum memberikan kebenaran formil atas akta autentik, kebenaran tersebut meliputi:

a) Kebenaran tanggal akta;

b) Kebenaran yang ada pada akta tersebut;

c) Kebenaran identitas tentang para pihak yang hadir dalam pembuatan akta;

d) Kebenaran terhadap tempat dimana akta tersebut dibuat. ${ }^{9}$

3. Kekuatan pembuktian materiil

Kekuatan pembuktian materiil dapat dilihat berdasarkan isi dari akta tersebut. Artinya bahwa isi dari akta tersebut merupakan keterangan yang diperoleh dari para pihak yang terdapat didalam akta adalah benar. Notaris mempunyai batasan mengenai pembuktian formil dalam akta. Seorang Notaris dalam membuktikan kebenaran materiil adalah bahwa memang benar bahwa para pihak telah memberikan keterangan sesuai dengan apa yang terdapat didalam akta. Namun Notaris tidak mempunyai kewenangan untuk mencari tau kebenaran lebih lanjut dalam keterangan para pihak tersebut.

Ketiga hal tersebut di atas merupakan sebuah kesempurnaan akta Notaris sebagai suatu akta autentik. Apabila dalam persidangan dapat dibuktikan bahwa ada salah satu aspek yang tidak terpenuhi, maka akta yang bersangkutan hanya mempunyai kekuatan pembuktian sebagai akta dibawah tangan ${ }^{10}$. Mengutip dari pernyataan Habib Adjie ${ }^{11}$ pada saat diselenggarakannya Seminar Magister Kenotariatan Universitas Islam Indonesia, bahwa telah terjadi kesalahan persepsi dalam memahami akta Notaris. Bahwa inti dari adanya akta Notaris, yaitu adanya keinginan atau kehendak dari para pihak, agar segala bentuk dan

${ }^{7}$ M. Luthfan Hadi Darus, Hukum Notariat dan Tanggung Jawab Jabatan Notaris, Cetakan Pertama, UII Press, Yogyakarta, 2017, hlm. 25.

8 Salim HS, Peraturan Jabatan Notaris, Cetakan Pertama, Cahaya Prima Sentosa, Jakarta, 2008, hlm. 30.

${ }^{9}$ Ibid., hlm. 30.

${ }^{10}$ Sjaifurrachman dan Habib Adjie, Aspek Pertanggungjawaban Notaris Dalam Pembuatan Akta, Mandar Maju, Bandung, 2001, hlm. 7.

${ }^{11}$ Habib Adjie, Merajut Pemikiran Dalam Dunia Notaris \& PPAT, Cetakan Keempat, Citra Aditya Bakti, Surabaya, 2010, hlm. 30 . 
tindakannya dituangkan ke dalam bentuk akta Notaris. Tanpa adanya keinginan atau kehendak para pihak tersebut tentunya Notaris tidak akan membuatkan akta itu untuk para pihak menjadi akta autentik dan Notaris juga memberikan bingkai formalitas agar akta tersebut menjadi alat bukti yang sempurna sesuai aturan hukum yang berlaku. Sehingga dapat dikatakan bahwa akta Notaris bukan merupakan perbuatan Notaris, dan Notaris bukanlah pihak dalam suatu akta.

Dalam praktiknya, akta yang dibuat oleh Notaris tidak jarang dipermasalahkan oleh salah satu pihak atau oleh pihak lain karena dianggap merugikan kepentingannya, baik itu adanya pengingkaran suatu isi akta, tanda tangan para pihak, kehadiran pihak di hadapan Notaris, atau bahkan adanya dugaan keterangan palsu dalam akta. Hal tersebut dapat mengakibatkan terlibatnya Notaris dalam kasus hukum. Berkaitan dengan masalah tersebut maka wajar saja jika Notaris bermaksud memberikan perlindungan kepada dirinya sendiri. Karena dalam menjalankan tugas dan jabatannya jika sudah mengikuti aturan yang ada dalam Undang-Undang Jabatan Notaris dan tidak melanggar kode etik tentunya sudah memberikan perlindungan yang tepat bagi Notaris sendiri. Tetapi untuk menambah perlindungan diri Notaris, sebagian Notaris mencantumkan suatu klausula pengamanan diri Notaris dalam akta yang dibuatnya yang biasanya disebut dengan klausula proteksi diri.

Tetapi dalam praktik sekarang ini sudah banyak terjadi akta yang dibuat oleh Notaris sebagai alat bukti autentik dipersoalkan di pengadilan. Bahkan banyak Notaris yang sampai dipanggil langsung ke Pengadilan sebagai saksi dan bisa saja digugat atau dituntut di muka Pengadilan. Penyebab permasalahan bisa timbul secara langsung akibat kelalaian seorang Notaris, bisa juga berasal dari ketidakjujuran orang lain. Apabila kesalahan itu berasal dari Notaris sendiri, dalam Pasal 84 UUJN maka akan berakibat akta tersebut akan terdegradasi menjadi akta di bawah tangan namun dapat pula akta tersebut menjadi batal demi hukum.

Pertanggungjawaban Notaris yang sebagai akibat pembatalan akta Notaris dilihat dari perbuatannya yang mengakibatkan pembatalan akta tersebut apakah diakibatkan adanya kesalahan atau kelalaian dari Notaris atau karena adanya perbuatan secara melawan hukum dari para pihak. Notaris tidak dapat dimintakan pertanggung jawaban jika batalnya akta tersebut akibat adanya kesalahan dari para pihak, bukan kesalahan dari Notaris.

Mengatasi hal tersebut karena jabatan Notaris merupakan jabatan pribadi, maka Notaris wajib melindungi dirinya sendiri dengan menjalankan tugas dan jabatannya menurut UUJN dan peraturan perundang-undangan lainnya. Tetapi 
Notaris terkadang meminta untuk mencantumkan pengamanan atau perlindungan diri untuk Notaris jika terjadi sengketa atau ada hal-hal lain yang kemudian hari terbukti tidak benar dari para penghadap. Misalnya pencantuman klausula pengamanan diri oleh Notaris dalam menjalankan tugas dan jabatannya terhadap akta yang dibuat misalnya sebagai berikut: seperti yang di temui penulis dalam akta RUPS Luar biasa (pernyataan keputusan rapat umum luar biasa para pemegang saham perseroan terbatas PT X ) di Kabupaten Sleman yaitu "penghadap menyatakan dengan ini menjamin kebenaran data, keterangan, dan identitas penghadap sesuai tanda pengenal yang disampaikan kepada saya Notaris, dan bertanggung jawab sepenuhnya atas hal tersebut dan tidak akan melibatkan Notaris dengan cara dan bentuk apapun.

\section{Rumusan Masalah}

Berdasarkan latar belakang di atas, maka rumusan masalah yang dapat diuraikan sebagai berikut. Pertama, bagaimana kekuatan hukum klausul pengamanan diri Notaris dalam akta jika ada penghadap yang menyangkal? Kedua, bagaimana klausul pengamanan diri dalam akta Partij dapat memberikan perlindungan hukum bagi Notaris dalam menjalankan tugas dan jabatan?

\section{Tujuan Penelitian}

Dengan Mengacu pada rumusan masalah di atas, maka tujuan penelitian ini adalah sebagai berikut: Pertama, untuk mengetahui kekuatan hukum klausul pengamanan diri Notaris dalam akta jika ada penghadap yang menyangkal. Kedua, untuk mengetahui klausul pengamanan diri dalam akta Partij dapat memberikan perlindungan hukum bagi Notaris dalam menjalankan tugas dan jabatannya.

\section{Metode Penelitian}

Jenis penelitian yang digunakan dalam kekuatan klausula pengaman diri dalam akta bagi Notaris adalah yuridis empiris atau sering disebut dengan penelitian hukum sosiologis atau penelitian lapangan, yaitu meneliti atau mengkaji tentang kenyataan hukum yang berlaku yang terjadi di masyarakat. ${ }^{12}$ Penelitian hukum ini dilakukan mengkaji kebenaran atau keadaan nyata yang terjadi di masyarakat untuk mendapatkan dan sekaligus mengetahui fakta dan data yang dibutuhkan untuk diidentifikasi masalah agar memperoleh penyelesaian masalah (hukum dilihat dari norma atau das sollen). ${ }^{13}$

\footnotetext{
12 Bambang Waluyo, Penelitian Hukum dalam Praktek, Cetakan Pertama, Sinar Grafika, Jakarta, 2002, hlm. 15.

13 Ibid., hlm. 16.
} 


\section{Hasil Penelitian dan Pembahasan}

\section{Kekuatan Hukum Klausul Pengamanan Diri Notaris dalam Akta Jika Ada Penghadap yang Menyangkal}

Tanggung jawab Notaris dalam menjalankan jabatannya sangat besar terhadap kelangsungan akta, dan akibat hukum yang terjadi dikemudian hari baik terhadap akta autentik maupun akta dibawah tangan yang disahkan oleh Notaris. Peranan tersebut merupakan suatu kewajiban yang diberikan oleh undang-undang dan merupakan implementasi atas keinginan pihak yang ingin melakukan perbuatan hukum. Sehingga akta yang dihasilkan dapat dipergunakan sebagai alat bukti yang sempurna apabila suatu saat terjadi sengketa. ${ }^{14}$ Notaris sebagai pejabat umum menjalankan sebagian dari kekuasaan negara di bidang hukum perdata terutama dalam membuat akta autentik (akta Notaris). Dalam pembuatan akta Notaris baik dalam bentuk partij akta ataupun relaas akta, Notaris bertanggung jawab supaya setiap akta yang dibuatnya mempunyai sifat autentik sebagaimana yang dimaksud dalam Pasal 1868 KUHPerdata.

Akta yang dibuat oleh Notaris harus sesuai dengan Undang-Undang Jabatan Notaris. Dikatakan sebagai akta autentik apabila pembuatannya sesuai sebagaia mana yang diatur dalam Pasal 38, Pasal 39 dan Pasal 40. Akta autentik yang dibuat oleh Notaris yang tidak mematuhi pasal tersebut akan mengakibatkan akta tersebut hanya mempunyai kekuatan pembuktian sebagai akta dibawah tangan. ${ }^{15}$ Pembuatan akta autentik berasal dari kehendak para pihak yang ingin membuat akta. Para pihak datang kepada Notaris untuk dibuatkan akta atas suatu perbuatan hukum tertentu yang menjadi kebutuhan para pihak dan dibuat oleh Notaris. ${ }^{16}$ Baik akta dibawah tangan maupun akta autentik harus memenuhi rumusan mengenai syarat sahnya suatu perjanjian didasarkan pada Pasal 1320 KUHPerdata yaitu: kesepakatan, kecakapan, hal tertentu, dan sebab yang diperbolehkan. ${ }^{17}$

a. Sepakat dimaksud bahwa kedua subjek yang mengadakan perjanjian itu harus bersepakat dan setuju mengenai hal-hal pokok dari perjanjian yang diadakan tersebut.

14 Wawan Setiawan, Sikap Profesionalisme Notaris Dalam Pembuatan Akta Autentik, Media Notariat Mei-Juni, 2004, hlm. 25.

15 Undang-Undang Jabatan Notaris Nomor 2 Tahun 2014 Pasal 41. hlm. 56.

${ }^{16}$ R.Soegondo Notodisoerjo, Hukum Notariat di Indonesia Suatu Penjelasan, PT Raja Grafindo, Jakarta, 1993,

${ }^{17}$ Habib Adjie, Merajut Pemikiran Dalam Dunia Notaris \& PPAT, Citra Aditya Bakti, Surabaya, 2010, hlm. 35. 
b. Kecakapan dimaksud bahwa orang yang membuat suatu perjanjian harus cakap menurut hukum. Pada asasnya setiap orang yang sudah dewasa atau akilbaliq dan sehat pikirannya adalah cakap menurut hukum. ${ }^{18}$ Orang yang cakap atau wenang untuk melakukan perbuatan hukum adalah orang yang sudah dewasa.

c. Hal tertentu dimaksud bahwa suatu perjanjian harus mengenai suatu hal tertentu. Dalam KUHPerdata hal tertentu adalah: hanya barang-barang yang dapat diperdagangkan yang dapat menjadi pokok suatu perjanjian, suatu barang yang dapat ditentukan jenisnya, atau barang-barang yang akan ada dikemudian hari. ${ }^{19}$

d. Causa yang halal, artinya mengandung causa/sebab yang dibenarkan oleh hukum/menurut hukum dalam arti tidak melanggar undang-undang, ketertiban umum dan/atau kesusilaan.

Selain syarat sahnya suatu perjanjian yang harus dipenuhi dalam pembuatan kontrak di dalam akta, Notaris juga harus memperhatikan asas-asas dalam hukum perjanjian. Asas-asas tersebut adalah sebagai berikut:

a. Asas kebebasan berkontrak

Dalam Pasal 1338 ayat (1) KUHPerdata berbunyi: semua perjanjian yang dibuat secara sah berlaku sebagai undang-undang bagi mereka yang membuatnya. Asas kebebasan berkontrak dalam arti kata materiil bahwa para pihak bebas mengadakan kontrak mengenai hal yang mereka inginkan asalkan causanya halal. Artinya asas tersebut memberikan kebebasan berkontrak kepada pihak untuk membuat atau tidak membuat perjanjian, mengadakan perjanjian dengan siapapun, menentukan isi perjanjian, pelaksanaan serta persyaratannya. ${ }^{20}$

b. Asas konsensualisme

Asas konsensualisme memberikan pandangan bahwa perjanjian yang pada umumnya tidak diadakan secara formal, tetapi perjanjian adalah cukup dengan adanya kesepakatan antara para pihak. ${ }^{21}$ Dalam Pasal 1338 ayat (1) KUHPerdata disebutkan bahwa semua perjanjian yang dibuat berlaku secara sah sebagai undang-undang bagi mereka yang membuatnya. Didalam pasal tersebut ditemukan asas konsensualisme yaitu 'perjanjian dibuat secara sah' dengan merujuk pada Pasal 1320 syarat sahnya perjanjian yaitu sepakat mengikat dirinya (consensus). Asas konsensualisme berarti bahwa perjanjian itu terbentuk atau lahir pada saat tercapainya kata sepakat dari para pihak yang mengikat dirinya. ${ }^{22}$

\footnotetext{
18 Subekti, Hukum Perjanjian, cetakan kesembilanbelas, PT Intermasa, Jakarta, 2002, hlm. 17.

${ }_{19}$ Mulyoto, Perjanjian (Tehnik, Cara Membuat, dan Hukum Perjanjian yang Harus Dikuasai), Cakrawala Media, Yogyakarta, 2012, hlm. 34.

${ }^{20}$ H. Salim HS, et.al., Perancangan Kontrak dan Memorandum of Understanding (MoU), Cetakan Kelima, Sinar Grafika, Jakarta, 2006, hlm. 2.

${ }^{21}$ Herry Susanto, Peran Notaris Dalam Menciptakan Kepatutan Dalam Kontrak, Cetakan Pertama, FH UII Press, Yogyakarta, 2010, hlm. 31.

22 Ibid., hlm. 32
} 
c. Asas itikad baik

Asas itikad baik diatur dalam Pasal 1338 ayat (3) KUHPerdata, artinya asas ini bertindak sebagai pribadi yang baik dan pribadi yang jujur yaitu apa yang terletak pada seseorang pada waktu diadakan perbuatan hukum. ${ }^{23}$

d. Asas kepercayaan

Maksud dari asas ini yaitu seseorang yang akan mengadakan perjanjian dengan pihak lain, menumbuhkan kepercayaan diantara kedua pihak itu bahwa satu sama lain akan memegang janjinya atau akan memenuhi prestasi. Dengan kepercayaan tersebut kedua belah pihak akan mengikatkan dirinya sehingga perjanjian tersebut mempunyai kekuatan mengikat sebagai undang-undang.

e. Asas pacta sunt servanda(asas kekuatan mengikat)

Dalam Pasal 1338 ayat (1) KUHPerdata menyatakan bahwa semua perjanjian yang dibuat secara sah berlaku sebagai undang-undang bagi mereka yang membuatnya. Dengan kata lain, asas ini akan mendapatkan kepastian hukum bagi para pihak, maka sejak dipenuhinya syarat sahnya perjanjian maka sejak itu pula perjanjian mengikat para pihak seperti undang-undang. ${ }^{24}$

Menurut Rio Kustianto Wironegoro Notaris-PPAT Kota Yogyakarta, produk akta Notaris adalah produk keperdataan. Keperdataan merupakan bukti formal (apa yang ditunjukan kepada Notaris). Artinya akta autentik yang memuat kebenaran formal yaitu sesuai dengan apa yang diberikan para pihak kepada Notaris. Pada dasarnya seorang Notaris tidak bertanggung jawab dan tidak dapat dipertanggungjawabkan secara hukum terhadap kebenaran meteriil, oleh karena itu Notaris dalam menjalankan tugas dan tanggung jawabnya perlu kehati-hatian. Dalam membuat suatu akta Notaris akan meminta dasar kewenangan bertindak para penghadap, selain itu juga Notaris akan meminta dokumen-dokumen pendukung yang berhubungan dengan akta yang akan dibuatnya seperti identitas penghadap, surat kuasa apabila dikuasakan dan dokumen lain yang merupakan dasar pembuatan akta.

Memasukkan suatu klausula pada bagian badan akta sebelum akhir akta yang berbunyi "bahwa semua surat atau dokumen yang diperlihatkan kepada saya Notaris kemudian dicantumkan di dalam akta ini adalah benar, jika suatu hari terbukti tidak benar maka akan menjadi tanggung jawab para penghadap sepenuhnya dan membebaskan Notaris dari akibat hukum secara perdata maupun pidana". Secara asas sebenarnya klausula tersebut tidak usah ditulis karena Notaris hanya bertanggung jawab secara keperdataan yang merupakan

${ }^{23}$ Ibid., hlm. 33.

${ }^{24}$ Ibid., hlm. 36. 
bukti formal. Harus dipahami bahwa Notaris tidak mempunyai tanggung jawab untuk menilai kebenaran materiil dari data atau informasi yang diterangkan oleh para pihak dalam aktanya. Didalam prinsip tidak ada efek klausul pengaman tersebut. Tetapi jika Notaris ingin memasukkan klausul tersebut juga tidak salah untuk memperjelas aktanya. Tetapi jika klausul tersebut tidak dimasukkan juga tidak salah karena tidak menyebabkan Notarisnya menjadi lemah. ${ }^{25}$

Anatomi akta sangat penting, karena apabila Notaris dalam membuat akta tidak mematuhi ketentuan dalam peraturan perundang-undangan, maka akta tersebut tidak memenuhi syarat sebagai akta autentik, sehingga mengakibatkan akta tersebut hanya memiliki kekuatan pembuktian sebatas perjanjian dibawah tangan apabila telah ditandatangani oleh para pihak. Berikut Dalam UndangUndang Jabatan Notaris Pasal 38 diatur mengenai ketentuan akta yaitu:

(1) Setiap Akta Notaris terdiri atas:

a. Awal akta atau kepala akta;

b. Badan akta;

c. Akhir akta atau penutup akta

(2) Awal akta atau kepala akta memuat:Judul akta;
a. Nomor akta;
b. Jam, hari, tanggal, bulan, dan tahun;
c. Nama lengkap dan tempat kedudukan Notaris

(3) Badan akta memuat:
a. Nama lengkap, tempat dan tanggal lahir, kewarganegaraan, pekerjaan, jabatan, kedudukan, tempat tinggal para penghadap dan/atau orang yang mereka wakil;
b. Keterangan mengenai kedudukan bertindak penghadap;
c. Isi akta yang merupakan kehendak dan keinginan dari pihak yang berkepentingan;
d. Nama lengkap, tempat dan tanggal lahir, serta pekerjaan, jabatan, kedudukan, dan tempat tinggal dari tiap-tiap saksi pengenal.

(4) Akhir atau penutup akta memuat:

a. Uraian tentang pembacaan akta sebagaimana dimaksud dalam pasal 16 ayat (1) huruf I atau Pasal 16 ayat (7);

b. Uraian tentang penandatanganan dan tempat penandatanganan atau penerjemahan akta apabila ada;

c. Nama lengkap, tempat dan tanggal lahir, pekerjaan, jabatan, kedudukan, dan tempat tinggal dari tiap-tiap saksi akta;

d. Uraian tentang tidak adanya perubahan yang terjadi dalam pembuatan akta atau uraian tentang adanya perubahan yang dapat berupa penambahan, pencoretan, atau penggantian. 
Menurut Hendrik Budi Untung selaku Notaris-PPAT di Kota Yogyakarta, Klausul pengaman diri Notaris dalam akta jika ada penghadap yang menyangkal. Yang menyangkal dalam artian apakah penghadap tidak menghadap atau tidak hadir, apakah menyangkal bahwa dia tidak menandatangani akta tersebut, ataukah penghadap menyangkal bahwa dia tidak melakukan fingerprint. ${ }^{26}$ Oleh karena dalam pembuatan akta harus sesuai dengan Undang-Undang No. 2 Tahun 2014 tentang perubahan atas Undang-Undang No. 30 Tahun 2004 tentang Jabatan Notaris. Penghadap tidak bisa menyangkal karena akta tersebut merupakan alat bukti yang sempurna maka penghadap benar-benar harus menghadap kepada kita selaku Notaris dan menandatangani akta tersebut di hadapan kita. Notaris harus betul-betul meminta tanda tangannya serta fingerprintnya dari para penghadap tersebut. Maksud dari Hendrik Budi Untung klausul pengaman tersebut adalah finger print. Ditinjau dari segi kepastian hukum, fingerprint/sidik jari lebih memberikan kepastian hukum karena setiap orang memiliki sidik jari yang berbeda-beda sehingga apabila dikemudian hari terjadi sengketa maka pihak yang bersangkutan tidak dapat menyangkalnya.

Menurut Undang-Undang Jabatan Notaris Pasal 16 ayat (1) huruf c disebutkan bahwa Notaris wajib melekatkan surat atau dokumen sidik jari penghadap pada minuta akta. Berdasarkan pasal tersebut, penambahan klausul pengamanan diri Notaris yang merupakan fingerprint dapat memperkuat pembuktian mengenai pembuatan akta autentik agar penghadap tidak dengan mudahnya melakukan pembantahan, mengingkari, atau menyangkal atas kebenaran akta autentik. ${ }^{27}$ Dalam menjalankan jabatannya Notaris harus berperan secara adil dan tidak boleh memihak. Notaris harus memberikan penjelasan dan informasi yang lengkap baik itu yang menyangkut hak ataupun kewajiban serta akibat hukum dari para pihak mengenai akta yang akan ditandatanganinya. ${ }^{28}$

\section{Pencantuman Klausul Pengaman Diri dalam Akta Partij}

Akta partij merupakan akta yang dibuat dihadapan Notaris. akta tersebut berisikan keterangan atau kehendak para pihak yang membuatnya atau menyuruh membuat akta itu. Ciri khas dari partij akta adalah terletak pada komparisi yang menjelaskan kewenangan para pihak yang menghadap kepada

26 Hasil Wawancara dengan Hendrik Budi Untung Notaris-PPAT Kota Yogyakarta, tertanggal 30 September 2020, pukul 10.00 WIB.

27 Virgin Nigita, Tesis: "Urgensi dan Implikasi hukum penerapan Sidik Jari Penghadap/Para Penghadap/Para Pihak Pada Minuta Akta Notaris", UII, Yogyakarta, 2017, hlm. 100.

${ }_{28}$ Budiono Herlieen, Kumpulan Tulisan Hukum Perdata dibidang Kenotariatan, Citra Aditya Bakti, Bandung, 2012, hlm. 22. 
Notaris untuk membuat akta. Akta partij dibuat atas dasar kesepakatan para pihak yang menghadap kepada Notaris dengan maksud agar keterangan yang diberikan itu dikonstatir oleh Notaris didalam suatu akta yang dibuat di hadapan Notaris. ${ }^{29}$ Pembuatan partij akta menjadi kewenangan Notaris didalam menuangkan kehendak para pihak selama tidak melanggar peraturan perundangundangan yang berlaku.

Akta para pihak atau partij akta mempunyai kekuatan pembuktian materiil, sehingga peristiwa atau perbuatan hukum yang dinyatakan oleh para pihak kemudian dituangkan Notaris ke dalam akta adalah benar-benar terjadi. Isi keterangan ataupun perbuatan hukum yang tercantum didalam akta itu berlaku terhadap orang-orang yang memberikan keterangan itu dan untuk keuntungan serta kepentingan siapa akta itu diberikan. ${ }^{30}$

Menurut Habib Adjie akta Notaris mempunyai karakter yuridis yaitu sebagai berikut:

1) Akta Notaris wajib dibuat dalam bentuk yang sudah ditentukan oleh UUJN;

2) Akta Notaris dibuat karena ada permintaan para pihak sehingga jelas bahwa bukan keinginan dari Notaris sendiri;

3) Meskipun didalam akta terdapat nama Notaris, tetapi Notaris tidak berkedudukan sebagai pihak atau bersama-sama para pihak atau penghadap yang namanya tercantum dalam akta;

4) Mempunyai kekuatan pembuktian yang sempurna, sehingga siapapun tidak dapat menafsirkan lain, selain yang tercantum didalam akta;

5) Pembatalan daya ikat akta Notaris hanya dapat dilakukan atas kesepakatan para pihak yang namanya tercantum didalam akta. Apabila salah satu pihak ada yang tidak setuju, maka pihak tersebut harus mengajukan permohonan ke pengadilan umum agar akta tersebut tidak mengikat lagi dengan alasan tertentu dan dapat dibuktikan. ${ }^{31}$

Menurut Rio Kustianto Wironegoro Notaris-PPAT Kota Yogyakarta jika klausula tersebut dicantumkan ke dalam akta Notaris sebaiknya dicantumkan di akhir akta (sebelum demikian akta ini) sebelum penutup akta/akhir akta. Prinsipnya semua akta bisa dicantumkan klausula tersebut. Apabila dengan tidak dicantumkan apakah Notaris terlindungi? Secara asas hukum tetap terlindungi.

Menurut Hendrik Budi Untung Notaris-PPAT Kota Yogyakarta, Klausul (frasa)" tersebut boleh dimasukkan ke dalam akta, tetapi harus dengan mencocokkan identitas penghadap seperi KTP, surat Nikah, kartu keluarga, NPWP, harus dicocokkan semua. Apalagi ditambah dengan adanya penghadap

\footnotetext{
${ }^{29}$ Habib Adjie, Op. Cit., hlm. 67.

30 Ibid., hlm. 7

${ }^{31}$ Habib Adjie, Op. Cit., hlm. 71.
} 
yang mempunyai nama berbeda. Kasus tersebut harus dibuat pernyataan beda nama. Menurut penulis kesimpulan dari wawancara tersebut adalah tanggung jawab Notaris hanya sebatas kebenaran formil di dalam suatu akta. Notaris tidak mempunyai tanggung jawab untuk menilai kebenaran materiil dari informasi yang diperoleh dari para penghadap. Notaris pada umumnya hanya akan mencatat apa yang diterangkan oleh para penghadap yang menghadap kepadanya dan tidak ada kewajiban untuk mencari tahu kebenaran tersebut. Notaris bisa saja berbuat kesalahan karena keterangan dari para pihak yang tidak benar baik disengaja maupun tidak disengaja. Oleh karena itu, kesalahan demikian tidak bisa dipertanggungjawabkan kepada Notaris karena isi akta tersebut sudah dikonfirmasi kepada para pihak oleh Notaris dan perlu dipahami bahwa Notaris bukanlah pihak dalam suatu akta. Seorang Notaris harus memberikan informasi hukum yang penting dan benar kepada para pihak agar para pihak dapat mengerti betul dan tidak akan menimbulkan masalah di kemudian harinya.

Hal lain yang perlu diperhatikan yaitu Notaris dalam menjalankan tugasnya yang berkaitan dengan perlindungan hukum dengan pencantuman klausula pengaman diri Notaris dalam akta merupakan bentuk kehati-hatian Notaris atau untuk memperjelas aktanya. Namun, pencantuman klausula (frasa) tersebut tidak mempunyai efek di dalam aktanya. Sehingga apabila Notaris mencantukan atau tidak, maka tidak menjadi masalah karena tidak membuat akta Notaris menjadi lemah. Berbeda halnya dengan pencantuman klausula pengaman diri Notaris dalam bentuk fingerprint. Ditinjau dari segi kepastian hukum fingerprint lebih memberikan rasa aman dan kepastian hukum sehingga apabila dikemudian hari terjadi sengketa, pihak yang bersangkutan tidak dapat menyangkal atau mengingkarinya karena setiap orang memiliki sidik jari/fingerprint yang berbedabeda.

Kesimpulan secara umum terkait dengan pembahasan dari bab ini, penulis dapat menarik kesimpulan bahwa berdasarkan UUJN diatur bahwa Notaris adalah pejabat umum yang berwenang membuat akta autentik mengenai semua perbuatan, perjanjian, penetapan, dan peristiwa hukum. Akta Notaris sebagai akta autentik mempunyai kekuatan pembuktian yang sempurna. Dikatakan sempurna karena akta autentik memiliki kekuatan pembuktian lahiriah, formal, dan material serta dibuat oleh pejabat yang mendapatkan kepercayaan dari Negara untuk menjalankan fungsi administrasi negara sehingga legalitasnya dapat dipastikan. Oleh karena itu, Notaris harus memperhatikan dan teliti dalam proses pembuatan akta autentik. Dimana akta Notaris bentuk aslinya merupakan 
suatu perjanjian yang mengikat para pihak yang memiliki kepentingan. Sehingga akta Notaris harus memenuhi syarat sahnya suatu perjanjian yang telah diatur dalam Pasal 1320 yaitu kesepakatan, cakap berbuat hukum, hal tertentu, dan causa yang halal.

Menurut Pasal 1320 KUHPerdata yang mana dalam pasal tersebut memiliki syarat subjektif dan objektif yang harus dipenuhi. Apabila syarat subjektif yang terletak dibagian awal (sepakat) tidak terpenuhi, maka akta tersebut dapat dibatalkan oleh para pihak yang berkepentingan sehingga tidak mengikat mereka lagi. Kemudian apabila syarat objektif yang terletak pada badan isi yang memuat tentang apa yang diperjanjikan nyata dan tidak bertentangan dengan hukum, tidak terpenuhi maka akta tersebut dianggap tidak pernah ada dan tidak mengikat para pihak, sehingga akta tersebut batal demi hukum.

Dalam menjalankan jabatannya Notaris harus berperan secara adil dan tidak boleh memihak kepada salah satu pihak, termasuk dalam hal pembuatan akta. Para pihak datang kepada Notaris menceritakan keinginannya dengan maksud agar perbuatan hukumnya tersebut dapat dituangkan kedalam akta autentik sehingga para pihak memiliki kepastian hukum. Akta autentik yang dibuat oleh Notaris merupakan alat bukti yang sempurna, pembuktiannya memiliki arti yuridis yaitu hanya mengikat para pihak yang terlibat dalam akta tersebut yang melahirkan hak dan kewajiban bagi para pihak sesuai yang tercantum didalam akta.

\section{Penutup}

Berdasarkan pembahasan di atas, maka kesimpulan yang dapat diambil dalam penelitian ini yaitu, pertama, pencantuman klausula pengamanan diri Notaris dalam akta tidak mempunyai kekuatan hukum atau tidak mempunyai efek di dalam akta Notaris. Tetapi apabila Notaris ingin tetap mencantumkan klausula pengamanan diri tersebut didalam aktanya juga tidak salah dan tidak mengurangi atau tidak membuat Notaris menjadi lemah. Notaris selaku pejabat umum pada dasarnya telah mendapatkan perlindungan hukum yang cukup dari Undang-Undang Jabatan Notaris diantaranya dengan dibentuknya majelis pengawas dan majelis kehormatan Notaris yang bertugas untuk mengawasi, membina serta mendampingi Notaris dalam menjalankan tugas dan jabatannya sesuai peraturan perundang-undangan yang berlaku. Apabila dengan dicantumkannya klausula tersebut di dalam akta Notaris kemudian isi akta dipermasalahkan oleh para pihak dengan mengingkari atau menyangkal kebenaran yang ada dalam isi akta tersebut maka harus diketahui bahwa akta Notaris merupakan produk keperdataan yang memuat kebenaran formil. Notaris 
tidak mempunyai tanggung jawab untuk menilai keberanaran materiil dari data atau informasi yang diberikan oleh para pihak sehingga apa yang ada dalam suatu akta harus dilihat apa adanya, tidak perlu dinilai atau ditafsirkan lain selain apa yang tertulis didalam akta tersebut.

Kedua, apabila Notaris ingin memproteksi dirinya dengan mencantumkan klausula pengamanan diri dalam aktanya sebaiknya berupa lampiran fingerprint yang merupakan dokumen pendukung dan pelengkap dalam akta Notaris. Adanya lampiran tersebut memberikan perlindungan kepada Notaris dan aktanya. Menurut undang-undang Jabatan Notaris dan kode etik Notaris telah mengatur tentang klausula tersebut yakni menyangkut tentang fingerprint, sehingga para pihak tidak bisa mengingkari atau menyangkal isi akta Notaris. Hal ini disebabkan karena tanggung jawab Notaris hanyalah sebatas kebenaran formil dalam suatu akta. Notaris hanya menuangkan suatu perbuatan hukum yang dilakukan oleh para pihak kedalam akta autentik dan menyesuaikan syaratsyarat formil dengan yang sebenarnya lalu menuangkan kedalam akta. Apabila isi akta dipermasalahkan oleh para pihak atau pihak lainnya sebenarnya merupakan permasalahan mereka sendiri. Tetapi hal tersebut masih kurang dipahami oleh para penegak hukum yang sering melibatkan Notaris dalam permasalahan tersebut. Untuk meminimalisir Notaris ikut terlibat dalam faktor eksternal, Notaris mencantumkan klausula pengamanan diri dalam aktanya.

Pentingnya untuk diadakan pendidikan atau penyuluhan hukum bagi seluruh jajaran penegak hukum dan masyarakat agar lebih mengetahui batasanbatasan mengenai tanggung jawab khususnya di bidang Notaris sehingga tidak ada lagi dugaan atau menyeret Notaris dalam permasalahan yang terjadi diantara para pihak serta penyuluhan hukum kepada masyarakat untuk tetap jujur dan beritikad baik dalam melakukan suatu perbuatan hukum. Kemudian apabila Notaris ingin memberikan perlindungan hukum dalam menjalankan tugas dan jabatannya yaitu dengan mencantumkan klausula pengamanan diri berupa lampiran fingerprint. Sidik jari (fingerprint) adalah hasil reproduksi tapak jari baik yang sengaja diambil, dicapkan dengan tinta, maupun bekas yang ditinggalkan pada benda karena pernah tersentuh kulit telapak tangan atau kaki.

Fingerprint berfungsi untuk memberikan jaminan kepastian hukum mengenai kebenaran identitas penghadap karena sidik jari tidak dapat dipalsukan. Sidik jari ini dinilai penting disaat terjadi suatu sengketa dikemudian hari sebagai alat bukti bahwa seseorang benar telah menandatangani minuta akta tersebut. Jika hanya tandatangan saja maka dapat disangkal atau dikatakan palsu meskipun benar seseorang itu yang dulu menandatangani akta tersebut, karena 
tidak ada bukti lain yang menyatakan bahwa tandatangan tersebut dilakukan sendiri olehnya.

\section{Daftar Pustaka}

\section{Buku}

Anshori, Ghofur, Abdul, Perspektif Hukum Dan Etika, Lembaga Kenotariatan Indonesia, Cetakan Pertama, UII Press, Yoyakarta, 2009.

Adjie, Habib, dan Sjaifurrachman, Aspek Pertanggungjawaban Notaris Dalam Pembuatan Akta, Mandar Maju, Bandung, 2001.

Adjie, Habib, Merajut Pemikiran Dalam Dunia Notaris \& PPAT, Cetakan Keempat, Citra Aditya Bakti, Surabaya, 2010.

Darus, Hadi, M. Luthfan, Hukum Notariat dan Tanggung Jawab Jabatan Notaris, Cetakan Pertama, UII Press, Yogyakarta, 2017.

HS, Salim, Peraturan Jabatan Notaris, Cetakan Pertama, Cahaya Prima Sentosa, Jakarta, 2008.

Herlieen, Budiono, Kumpulan Tulisan Hukum Perdata dibidang Kenotariatan, Cetakan Kedua, Citra Aditya Bakti, Bandung, 2012.

Jimmy P \& M.Marwan, Kamus Hukum (Dictionary of Law Complate Edition, Cetakan kesatu, Reality Pulisher, Surabaya, 2009.

Kie, Thong, Thang, Studi Notariat dan Serba-Serbi Praktek Notaris, Cetakan Kedua , PT Ichtiar Baru Van Hoeve, Jakarta, 2011.

Mulyoto, Perjanjian (Tehnik, Cara Membuat, dan Hukum Perjanjian yang Harus Dikuasai), Cakrawala Media, Yogyakarta, 2012.

Notodisoerjo, R. Soegondo, Hukum Notariat di Indonesia Suatu Penjelasan, Cetakan Pertama, PT Raja Grafindo, Jakarta, 1993.

Sjaifurrachman, Aspek Pertanggungjawaban Notaris dalam Pembuatan Akta, Cetakan Pertama, Mandar Maju, Bandung, 2011.

Subekti, Hukum Perjanjian, cetakan kesembilan belas, PT Intermasa, Jakarta, 2002.

Subekti, R, Hukum Pembuktian, Cetakan Kedua, Pradnya Paramita, Jakarta, 2001.

Susanto, Herry, Peran Notaris Dalam Menciptakan Kepatutan Dalam Kontrak, Cetakan Pertama, FH UII Press, Yogyakarta, 2010.

\section{Hasil Penelitian/Tugas Akhir}

Nigita, Virgin, Tesis: "Urgensi dan Implikasi hukum penerapan Sidik Jari Penghadap/Para Penghadap/Para Pihak Pada Minuta Akta Notaris", (Yogyakarta, UII, 2017).

\section{Jurnal}

Wawan Setiawan, Sikap Profesionalisme Notaris Dalam Pembuatan Akta Autentik, Media Notariat, Edisi Mei-Juni, 2004.

\section{Peraturan Perundang-Undangan}

Undang-Undang Jabatan Notaris Nomor 2 Tahun 2014 Pasal 41. 


\section{Hasil Wawancara}

Hasil Wawancara dengan Bapak Rio Kustianto Wironegoro, Notaris-PPAT Kota Yogyakarta, tertanggal 16 September 2020, pukul 10.00 WIB.

Hasil Wawancara dengan Hendrik Budi Untung Notaris-PPAT Kota Yogyakarta, tertanggal 30 S eptember 2020, pukul 10.00 WIB. 